\title{
Dysfunctions in the territorial form: The case of Valencia
}

\author{
José Luis Miralles i Garcia \\ Departament d'Urbanisme, Universitat Politècnica de València. Valencia, Spain \\ E-mail: jlmirall@urb.upv.es
}

\begin{abstract}
It is possible to associate the idea of territorial harmony with the idea of territorial function. The perception of a territory with distributed uses that allow the observer to identify its functions and a landscape, urban and territorial, appropriate to the uses, generates a sense of harmony or order of "things", uses, in the territory. To the contrary, when, for example, people observe a natural space or resource as agricultural lands, where other external uses are located, such as industrial installations or transport infrastructures, the observer perceives a disorderly, degraded and dysfunctional landscape. This idea can serve as a basis to analyze the territorial forms. This article aims to analyze the territorial dysfunctions that have occurred in the process of transformation of the metropolitan area of Valencia and propose actions to manage the territory to sustainability. In metropolitan areas, such as the case of Valencia, there are usually spaces of great environmental value that give an environmental service as an ecological pantry for the population. However, in recent times, many of these spaces have undergone processes of urban sprawl that have produced a collapse of territorial harmony. In addition, mature metropolitan areas have low or no population growth while the artificial territory continues to increase. It is necessary to promote positive initiatives to identify and manage the green infrastructure. This implies a structural review of territorial management processes to achieve sustainability.
\end{abstract}

Keywords: Territorial quality, regional planning, territorial landscape, territorial management, urban sprawl

\section{Introduction}

Currently, European cities, in general, are in equilibrium situation of growth. The cities were grown during a long period. This period produced urbanized urban areas but also the urban sprawl phenomenon in periurban zones and a list of infrastructures networks that connect the sources of energy, natural resources and people trips with the city.

Particularly in Spain, with a strong tradition of urban planning, intervention on the territory and the city has focused mainly on urban development of the city, or expansion of the city, and, to a lesser extent, in the city built. The management system for urban development generates complete urban forms of the sectors that are developed. However, the rural land or "non-urbanizable" land (according to the name used in Spanish laws), when is not protected, accumulates diverse elements of all kinds that end up converting it, in many cases, in a "no place". Now, when cities cease to grow and urban borders consolidate, their degradation is appreciated. Until recently, these degraded edges were often spaces waiting for their urbanization. This situation made them into places and forms indefinite and, therefore, without harmony. And now also the absence of quality of that space indefinite of the urban borders is appreciated. Many of them have been generated by infrastructures. This paper intends to make an approximation to these degraded forms, to the processes and technical behaviors that have originated them and to possible forms of intervention. 


\section{Periurban dynamics}

Especially in the 21st century and during the urban expansion period 1997-2007 and the period of real estate crisis, from 2008 to the present, metropolitan areas have increased surfaces and decreased density.

This phenomenon is general. For example Wheeler (2017) studied the dynamics of six metropolitan regions of US in period 19802005, and concluded:

-Metropolitan areas had a very big increase of their urbanized areas and a very big increase of surface of metropolitan areas.

-Metropolitan areas had an important decrease of density both of population and houses in metropolitan regions.

In Spain, between 1997-2007, there was an expansive economic cycle based on real estate speculation that ended with the economic crisis that started in 2008 and which still stands today (Miralles, 2014) with special consequences in touristic coastal zones (Garcia-Ayllón, 2013).

Feria et al. (2016) studied the dynamics of metropolitan areas of Spain between 2001 and 2011. They observed that, in the case of Spain, metropolitan areas increased its populations during the period of real state bubble as you can see in Table 1. But in the crisis period, its population stopped or decreased. They think that this trend will continue. In spite of that, the processes of metropolitan areas expansions and urban sprawl keep going on and densities continue decreasing. That is the case of metropolitan area of Valencia, a metropolitan area next to Mediterranean Sea.

So it is necessary to know the new reality of metropolitan areas to generate policies in order

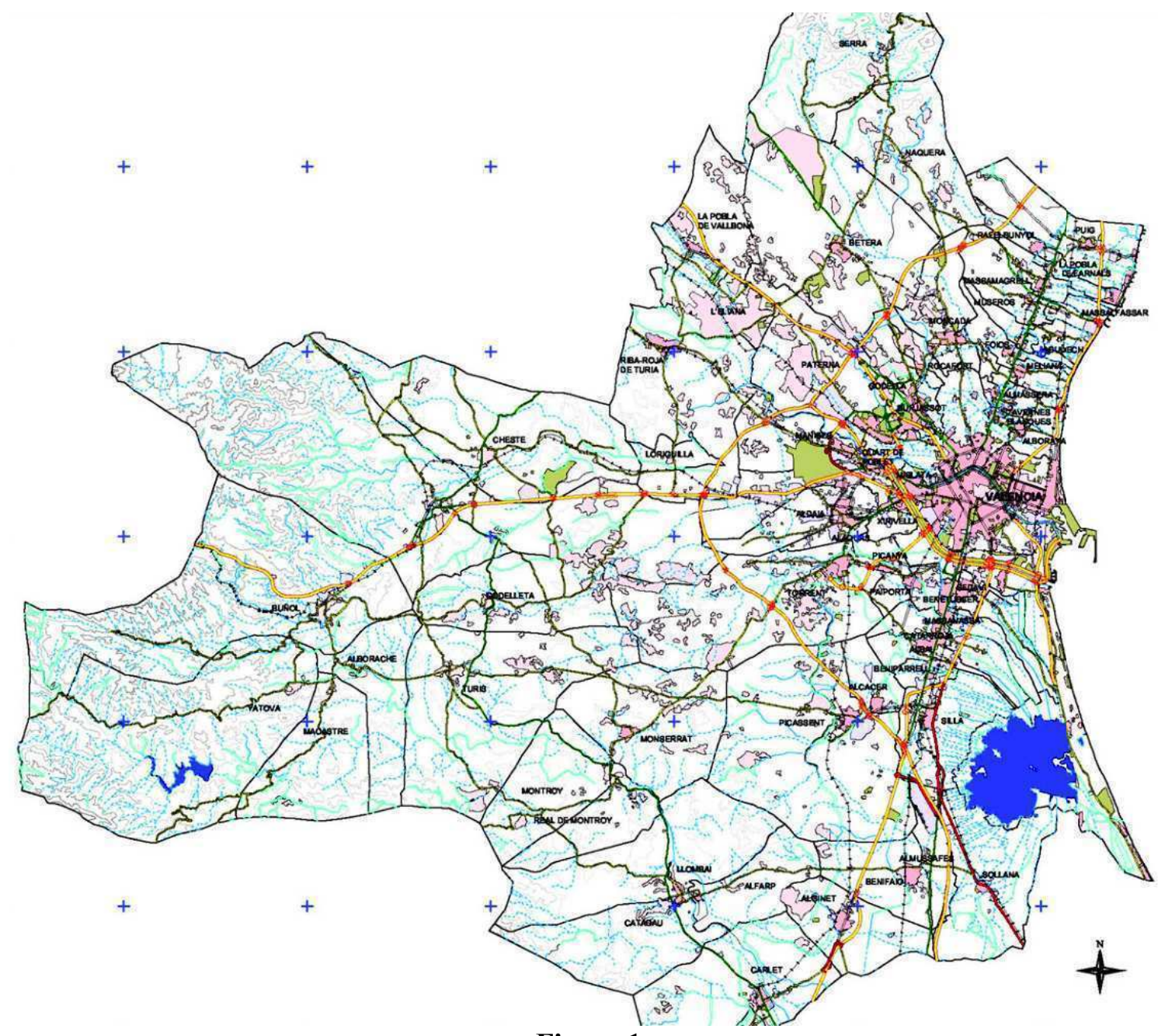

Figure 1.

Metropolitan area of Valencia. Source: UDR F.Eiximenis. 
Figure 2.

High Speed Train infrastructure seen from the bridge to pass.

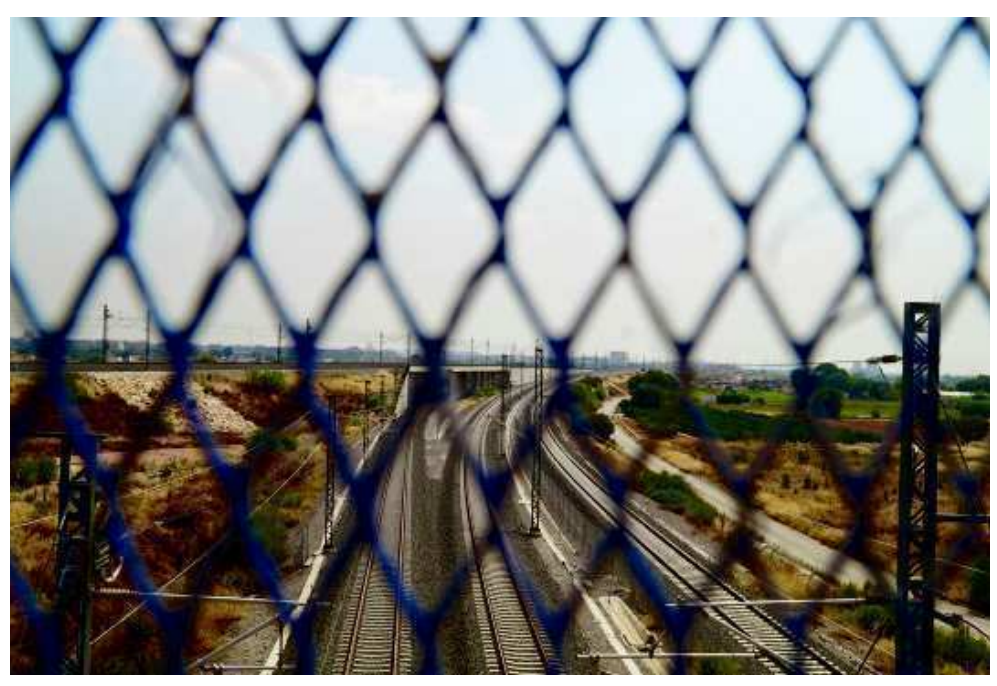

Figure 3.

Indefinite places between infrastructures.

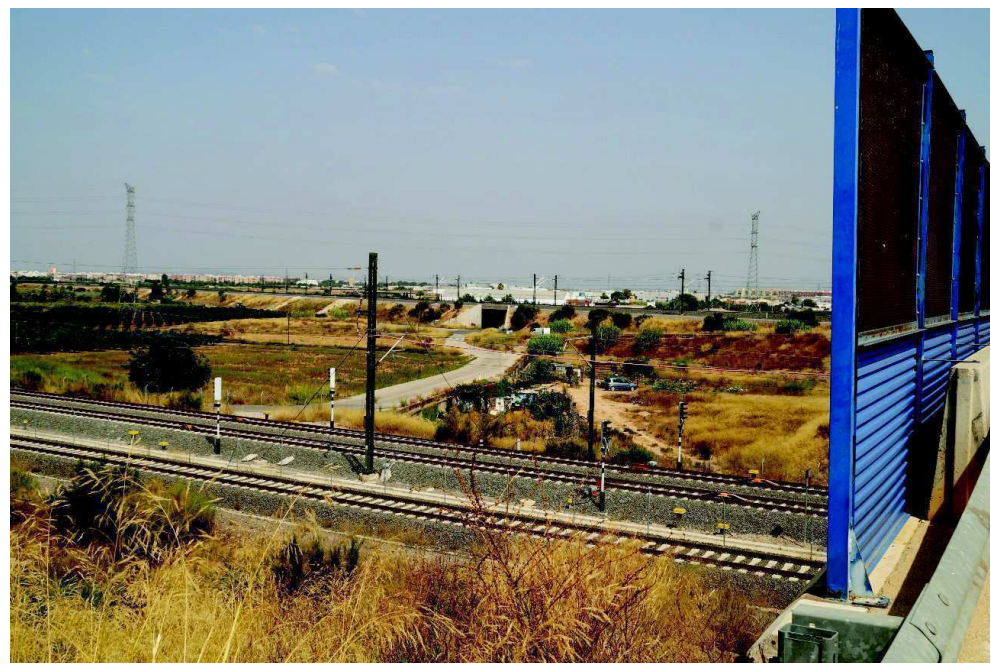

to improve sustainability on metropolitan territory by a new kind of planning (Miralles, 2015a). In this situation, environmental issues process to strategic environmental assessment are essential.

In the metropolitan area of Valencia different borders can be identified in function of a list of criteria. According Valencian Community's Territorial Strategy (GVA), the functional area of Valencia covers an area of $3,897 \mathrm{~km} 2$ with a population of 1,774,550 inhabitants in 2015 . The area includes 90 municipalities. In Fig. 1 , it can be seen the surface occupied by the metropolitan area according a study realized by the author's research team UDR F.Eiximenis in 2003. The surface of metropolitan area in 2003 was very similar to the current one.

In 2005, the population of this area was $1,740,335$ inhabitants that increased to $1,807,826$ in 2015 according to the data of
Initial Document for Strategic Environmental Assessment or Draft Plan of Metropolitan Plan of Valencia (GVA). In addition, there are 895 ha of urbanized land with a capacity for 22,375 new homes and 1,280 ha of commercial and industrial urbanized lands with a capacity for 51,200 new employees.

So, metropolitan area has had a moderate increase between 2005 and 2015. However, as shows Table 2, artificial surface has had a large increase according Boira (2011).

In addition there is an important amount of land prepared for urban development, as shows Table 3. With an average density of 25 homes/ha, land planned for residential developments in urban plans (urbanizable lands) has a capacity for about 150,000 new homes or 375,000 inhabitants. On the other hand, land for economic activities, with a ratio of 40 employees/ha, has a capacity for about 138,000 new employees. 
Figure 4.

. The 'new' landscapes of High Speed Train infrastructure on metropolitan rural areas of Valencia.

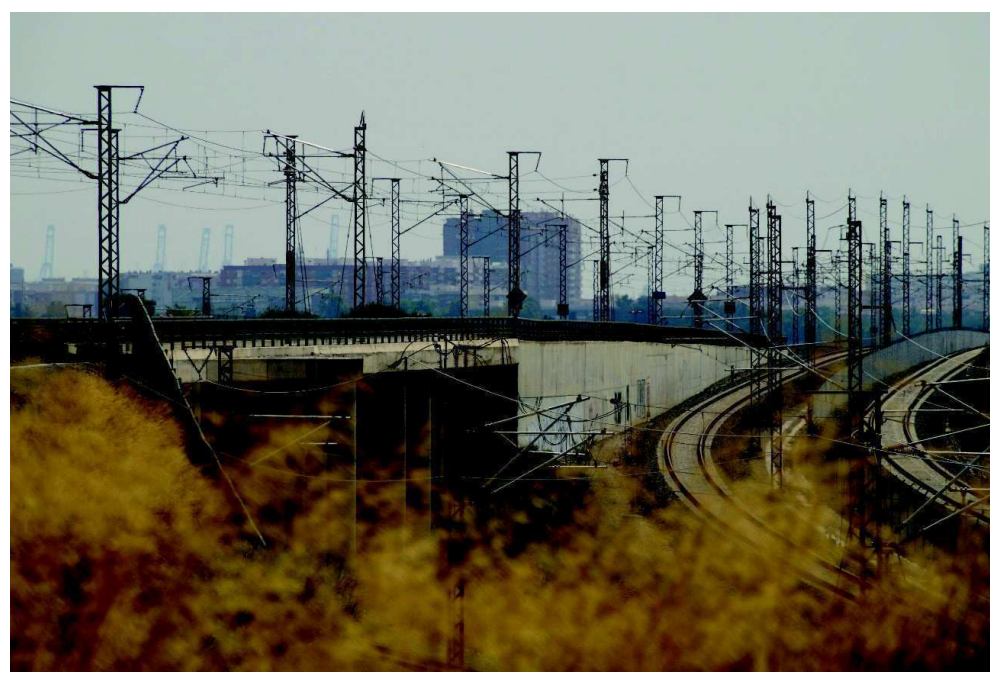

Figure 5.

Chaotic mix uses in metropolitan rural area of Valencia.

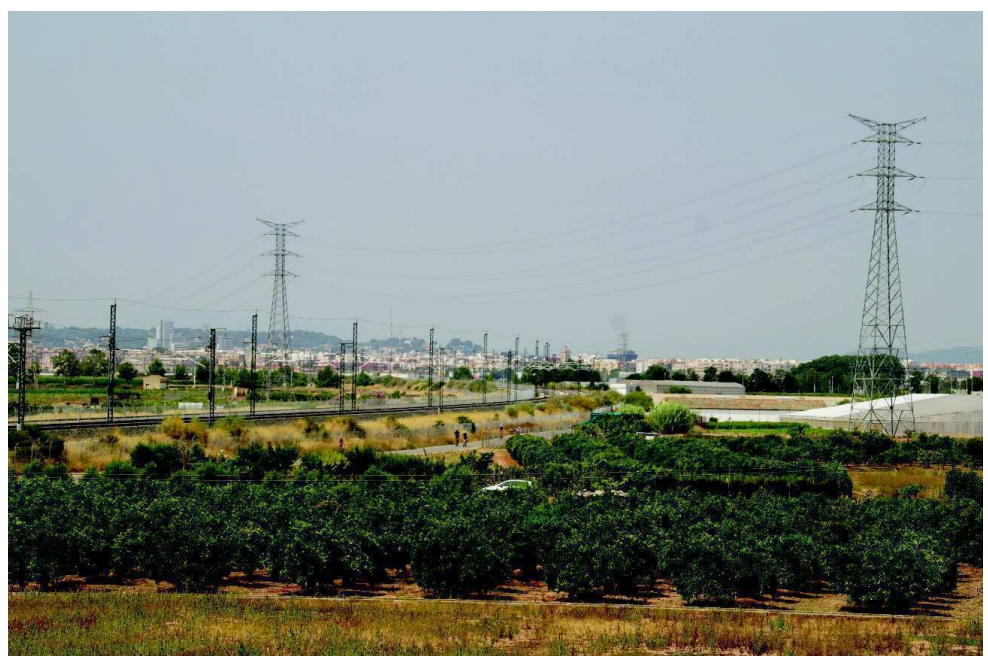

All this means that although population does not grow just a little, urban use is increasing in a very intensive way. Urban expansion in metropolitan area of Valencia has taken place in the form of urban sprawl as can be seen in Fig. 1. This involves an increase in the cost of municipal public services (Gielen, 2016) (Gielen et al, 2017).

On the other hand, this intensive process of urban expansion and sprawl produces important environmental impacts. In fact, in addition, this urban expansion is completed by all type of uses in rural land or "not urbanizable land" (named according to legal Spanish qualification). Really, a great part of metropolitan area is a mix of urban areas and rural areas with high level of artificial uses of houses, facilities and infrastructure networks (routes, motorways, rail trains, electric energy lines, water channels ...).
The final result for metropolitan urban areas is a landscape of a chaotic mix of isolated urban and rural uses without any harmony. In contrast with urban areas that are organized according to an urban plan, the metropolitan rural areas have no criterion for their ordination. Usually it is only an overlap of different uses on the territory according to partial criteria and without a global landscape vision. Some examples of the real situation on Valencia metropolitan area are shown in images 2, 3, 4 and 5 .

\section{Environmental intervention instruments without success}

Paradoxically, the European Union has developed instruments of environmental intervention in the territory or environmental 
control of interventions in the territory for a long time. The Environmental Impact Directive of the projects, including the civil works projects of the infrastructure networks that supply natural resources to the cities, dates back to 1986, that is, 31 years ago. And the Directive on environmental assessment of plans and programs or strategic environmental assessment was approved in 2001, that is, 16 years ago.

If we look at the figures 2,3 and 4 corresponding to the infrastructure of the high-speed train built about the year 2010, the landscape integration shines by its absence. These cases occur systematically and the example noted is no exception. It is still the usual way of designing public works practiced by civil engineers in Spain and, what is worse, is still the way of projecting civil works that is taught in the Civil Engineering Schools (Engineering of Roads, Channels and Ports according to the Spanish name) of the Spanish universities. This has been evident in the project to expand the $\mathrm{V}-30$ recently exposed to the public.

Environmental impact studies, strategic environmental assessment, landscape integration or landscape altered by civil works are often considered as bureaucratic obstacles to overcome or obstacles to overcome. Often, these studies are contracted with the objective of justifying environmentally the previously decided solutions. The interest in drafting civil works projects that generate landscapes with a certain quality is minimal and the facts, which are evident in the images that are offered, demonstrate this.

\section{The landscape of the borders}

As a result of the above-mentioned dynamics, large metropolitan areas are largely occupied by degraded rural areas, especially urban borders. These areas not have a specific vocation, are indefinite. In theory, they are rural areas but in fact are areas with mixtures of uses that break the rural landscape and the economic continuity of the rural uses of the territory.

Conventional planning is not intended to address and intervene in these areas primarily because of the scale of work. The intervention must be carried out practically at the project level in order to define the detail.

On the other hand, if the scale of intervention in these edge landscapes has to be a project scale, the appropriate moment to define the intervention is the moment of definition of the project that produces these indefinite spaces. This implies consideration of three aspects.

On the one hand, the scope of the project definition, for example in the case of a railway infrastructure, cannot be strictly reduced to the land that physically occupies the infrastructure, but must be extended to the residual spaces it generates and which will potentially be degraded with the objective to act upon them. That is, it is necessary to rearrange uses and activities in these spaces or even their use for activities in building or for activities such as urban gardens.

Secondly, guaranteeing intervention in these adjoining spaces implies practically expropriation. The expropriation of these adjoining lands has an economic cost that can be significant. The application of excessive expropriation prices for land with practically no usefulness in a free market situation, in compliance with the current legislation in Spain, highlights the need to review the theory of land ownership.

Thirdly, for this type of landscape intervention to be effective, the intervention methodology and the delimitation of areas potentially at risk of degradation should be established as a rule. Otherwise, as is the current situation, the tendency is to minimize costs and, consequently, any type of intervention that envolving an additional cost. All this, although it is clear that the cause of these undefined landscapes is the civil work or intervention that is implemented in the territory breaking the preexisting rural landscape structure.

\section{Conclusion}

Although the population of metropolitan areas is stabilizing, the occupation of space in these areas has increased considerably. This dynamic has produced normally degraded periurban spaces adjoining the private and public 
facilities and infrastructure networks that cross these spaces to provide natural resources to cities.

Among the infrastructures that generate this type of spaces are the transport networks such as highways, roads and railroad, electric energy network, water supply and waste water networks ... In university schools, it is not properly formed to correct this landscape impacts and avoid the degraded landscapes that produce the infrastructures.

Studies and procedures for the evaluation of environmental impacts that today exist have failed to generate a landscape integration or landscape improvement of the areas degrade by the infrastructures.

It is necessary to define intervention methodologies in these urban borders that must be defined at the project level in the spaces adjacent to civil works or other elements that causes of landscape degradation.

\section{References}

Boira, J.V., (2011). 'Urbanismo expansivo: de la utopía a la realidad'. Proceedings of XXII Congreso de Geógrafos Españoles, 79-90.

Burriel de Orueta, E.L. (2009). 'La planificación territorial en la Comunidad Valenciana (1986-2009)'. Scripta nova, XIII (306). (http://www.ub.es/geocrit/sn/sn-306. htm) accessed 15 January 2017.

European Comission. Communication from the Commission to the European Parliament, the Council, the EESC and the CR. Green Infrastructure (GI) Enhancing Europe's Natural Capital. (http://eur-lex.europa.eu/legal-content/ EN/TXT/?uri=CELEX:52013DC0249) accessed 15 January 2017.

Feria Toribio, J.M. \& Martínez Bernabeu, L. (2016). 'La definición y delimitación del sistema metropolitano español: permanencias y cambios entre 2001 y 2011'. Revista Ciudad y Territorio. Estudios Territoriales, 187, 9-24.

García-Ayllón, S. (2013). Retrospective Analysis Of Urban Development In The Spanish Mediterranean Coast. WIT Transactions on Ecology and the
Environment, 179, 291-302.

Generalitat Valenciana (GVA). Conselleria d'Habitatge, Obres Públiques i Vertebració del Territori. Estrategia Territorial de la Comunitat Valenciana. Web site, Valencia, (http://www.habitatge.gva.es/web/ planificacion-territorial-e-infraestructuraverde/estrategia-territorial-de-la-comunitatvalenciana-77496) accessed on: 20 Feb. 2017.

Generalitat Valenciana (GVA). Conselleria d'Habitatge, Obres Públiques i Vertebració del Territori. Documento de Inicio del proceso de Evaluación Ambiental y Territorial Estratégica del Plan de Acción Territorial Metropolitano de Valencia. Web site, Valencia, (http://www.habitatge. gva.es/web/planificacion-territorial-einfraestructura-verde/plan-de-accionterritorial-metropolitano-de-valenciapateval-) accessed on: 20 Feb. 2017.

Gielen, E. (2016). Costes del urban sprawl para la administración local. El caso valenciano. (Publicacions de la Universitat de València).

Gielen, E., Riutort-Mayol, G., PalenciaJiménez, J.S. \& Cantarino, I. (2017). 'An urban sprawl index based on multivariate and Bayesian factor analysis with application at the municipality level in Valencia'. Environment and Planning B: Analytics and City Science. DOI: https:// doi.org/10.1177/2399808317690148.

Miralles i Garcia, J.L. (2014). El darrer cicle immobiliari al País Valencià. O el progrés de la misèria. (Fundació Nexe, València).

Miralles i Garcia, J.L. (2015a). 'Revising the basis for planning a new kind of progress: the case of Valencia's city'. WIT Transactions on The Built Environment, 148, 3-14.

Miralles i Garcia, J.L. (2015b). 'Environmental Management of Peri-urban Natural Resources: L'Horta de València case study'. WIT Transactions on Ecology and the Environment, 192, 99-110.

Vheeler, S.M. (2017). 'The Evolution of Built Landscapes in Metropolitan Regions'. Journal of Planning Education and Research, 27, 400-416. (www.//jpe.sagepub.com/cgi/ content/abstract/27/4/400) Accessed on 20 Feb. 2017. 


\section{Appendix}

Table 1. Population evolution of metropolitan areas of Spain. Source: Feria et al (2016).

\begin{tabular}{|l|r|r|r|r|}
\cline { 2 - 6 } \multicolumn{1}{c|}{} & \multicolumn{2}{c|}{2001} & \multicolumn{2}{c|}{2011} \\
\hline Metropolitan area & Municipalities & Population & Municipalities & Population \\
\hline Madrid & 172 & $5,623,784$ & 172 & $6,729,769$ \\
\hline Barcelona & 130 & $4,340,618$ & 139 & $5,088,201$ \\
\hline Valencia & 74 & $1,594,762$ & 80 & $1,935,363$ \\
\hline Sevilla & 49 & $1,369,708$ & 51 & $1,581,798$ \\
\hline Málaga-Marbella & 29 & $1,000,900$ & 25 & $1,239,954$ \\
\hline
\end{tabular}

Table 2. Population evolution and artificial land (technical terminology of the CORINE data base) of Valencia Urban Region (1990-2006). Source: Boira (2011).

\begin{tabular}{|l|c|r|r|}
\hline Artificial land (ha) & \multicolumn{1}{|c|}{1990} & \multicolumn{1}{c|}{2000} & \multicolumn{1}{c|}{2006} \\
\hline Valencian Community & $73.335,28$ & $109.612,90$ & $125.794,52$ \\
\hline Valencia Urban Region & $28.116,76$ & $36.363,74$ & $41.766,75$ \\
\hline
\end{tabular}

Table 3. Land for urban development. Source: GVA.

\begin{tabular}{|c|c|}
\hline Urbanizable land & Surface (ha) \\
\hline Residential & $6,138.86$ \\
\hline Public facilities & $1,987.26$ \\
\hline Economic activities & $4,464.07$ \\
\hline - $\quad$ Industrial & $3,468.74$ \\
\hline - $\quad$ Tertiary & 995.33 \\
\hline TOTAL & $12,590.19$ \\
\hline
\end{tabular}

